\title{
PARENTING PATTERNS OF PARENTS AND MENTAL- EMOTIONAL DEVELOPMENT IN TAMAN KANAK-KANAK DHARMA WANITA GODEAN, NGANJUK DISTRICT
}

\author{
Rahayu Budi Utami ${ }^{*}$, Amrina Rosada ${ }^{1}$ \\ ${ }^{1}$ STIKES Satria Bakti Nganjuk \\ *Correspondence: \\ Rahayu Budi Utami \\ Email: ayu_stikes_sb@yahoo.com
}

\begin{abstract}
Background: Growth and development on preschooler is the basic step that influenced the next development on their life thus it was called golden period. Preschooler's psychosocial development related on their mental process. One of the factor that influenced mentalemotional development is the lacked of parenatal affection or warmth and care to the children.

Objectives: This study aimed to describe and examine the correlation between parenting patterns and mental-emotional development at Taman Kanak-kanak Dharma Wanita Godean, Nganjuk District.

Method: Correlation method with case control approched was utilized on this research and implemented on March 27th of 2018 throughout March 29th of 2018 at Taman Kanak-kanak Dharma Wanita Godean Kabupaten Nganjuk. All preschoolers parents as many as 47 couple (94 people) at this Taman Kanak-kanak Dharma Wanita Godean Kabupaten Nganjuk was defined as the population sampling. This research utilized purposive sampling thus as many as 40 parents matched the inclusion and exclusion criteria. The parenting was independent variable and the mental-emotional development was the dependent variable. Statistical test used Spearmen Rho test.

Results: The outcome of the study was found that most parenting parents of 23 parents $(57,5 \%)$ had an authoritative parenting type, most of which were 23 elderly $(57,5 \%)$ was uneble to development mental-emotional approach and nearly half of the 18 parents (45 \%) have authoritative parenting style and unable to develop mental-emotional approach, alternate hypothesis (Ha) is accepted with rho value of 0,011 less than alpha value of $0,05(\mathrm{rho}=0,001 \leq \alpha=0,05)$.

Conclusion: Appropriate parenting corresponds child's growth and influenced mental-emotional child's development, parenting efficacy can be utilized for preventive measure on preschooler mental-emotional disorder.
\end{abstract}

Key words: Parenting, Mental-emotional development, Preschooler.

\section{INTRODUCTION}

Preschoolers are children between 3-6 years of age (Wong, 2009). Growth and development during preschool are the basic stages that are very influential and become the basis for further development. This period is short so it is called the critical period or golden period. There are 4 stages of development, including cognitive development, psychosocial development, psychosexual development, and moral development (Wong, 2008). Psychosocial development influences mental processes, where information processing processes that reach cognition, intelligence, thinking, learning, problem solving and concept formation activities (Prastito, 2010). Emotional mental problems can be defined as a situation that indicates an individual experience an emotional change that hinders, hinders, or complicates a person in his attempt to adjust to his environment and experience. According to Mashar (2011), many kinds of mental emotional disorders in preschoolers include aggressiveness, temper tantrum, withdrawal, fear of excessive, lack of affection, hypersensitivity, anxiety and suicide. Based on 
a preliminary study held on Friday, January 26, 2018 , it was found that out of 10 children, 7 preschool children $(70 \%)$ did not want their parents to be left behind and would cry on the floor when their parents were left in the form of mental emotional temper tantrum, 2 children (20\%) often hurt their friends by pinching and yelling at their friends which included in the form of mental emotional aggressiveness, and 1 child (10\%) showed angry facial expressions if his friend did not want to lend him toys that were included in form of mental emotional aggressiveness. The factors that affect mental emotional in preschool children are parenting, genetic factors, children's health conditions, family conditions (home atmosphere) and relationships with peers. Parenting factors are very influential on a child's mental emotional, because parenting is a condition or interaction between children and parents in life. Many parenting patterns can be used, according to Astutik (2008), the types of parenting include authoritarian parenting, neglecting parenting, indulgent parenting and authoritative parenting. According to Mashar (2011), the impact that arises in children who are not mentally emotionally controlled is that physical violence will occur both to themselves and to others until suicide occurs. To prevent the occurrence of mental emotional disorders in preschool children, optimal interaction between children and parents is needed. The interaction between children and parents in daily life is called parenting. Implementation of effective parenting can help children to control mental emotional. According to Luthfia \& Elsa (2014), parenting is very influential on children's mental emotional control. This study aimed to describe and examine the correlation between parenting patterns and mental-emotional development at Taman Kanak-Kanak Dharma Wanita Godean, Nganjuk District.

\section{METHODS}

Study Design

The study used a correlation with case control approach.

\section{Setting}

This research was conducted in Taman Kanak-Kanak Dharma Wanita Godean Nganjuk District.

\section{Research Subject}

The population is all parents in Taman Kanak-kanak Dharma Wanita Godean Nganjuk District as many as 47 parents (94 people). In this study using Non-Probability Sampling, namely purposive sampling. The sample in this study were all parents who have preschool children that fit the inclusion criteria, including one of preschool parents (father or mother), willing to be a respondent, a child who lives 1 house with parents. In addition, there are also exclusion criteria in the form of single parents, children who are in physical disorders (for example, physical disabilities).

\section{Instrument}

This research was conducted by giving parents' parenting questionnaires to parents (to measure parenting parents), and giving an Emotional Mental Problem Questionnaire (KMME) given to parents (to measure emotional mental development).

\section{Data Analysis}

The results of this study were analyzed using the Spearmen Rho test with value of $\alpha=0.05$.

\section{RESULTS}

Characteristics of Respondents by Age of Parents

Table 1. Distribution of Respondents by Age of Parents in Taman Kanak-kanak Dharma Wanita Godean Nganjuk District $(\mathrm{n}=40)$.

\begin{tabular}{ccccc}
\hline \multirow{2}{*}{$\begin{array}{c}\text { Fge } \\
\text { Years) }\end{array}$} & \multicolumn{2}{c}{ Father } & \multicolumn{2}{c}{ Mother } \\
\cline { 2 - 5 } & & Percentage & Frequency & $\begin{array}{c}\text { Percentage } \\
(\boldsymbol{\%})\end{array}$ \\
\hline $20-25$ & 3 & 7 & 10 & 25 \\
$26-29$ & 9 & 23 & 9 & 22 \\
$\geq 30$ & 28 & 70 & 21 & 53 \\
\hline Total & 40 & 100 & 40 & 100 \\
\hline \multicolumn{2}{l}{ Sources: Primary Data of Questionnaire }
\end{tabular}

Sources: Primary Data of Questionnaire

Based on the data above, it was found that most fathers (28 respondents $(70 \%)$ and mothers $(21$ respondents $(53 \%))$ were $\geq 30$ years old.

Characteristics of Respondents by Level of Education of Parents 
Based on the results of the research data in table 2, it was found that almost half of the 19 respondents $(47 \%)$ fathers had senior high school and most of the 26 respondents $(65 \%)$ mothers had senior high school.

Table 2. Distribution of Respondents by Level of Education of Parents in Taman Kanak-kanak Dharma Wanita Godean Nganjuk District $(\mathrm{n}=$ 40).

\begin{tabular}{ccccc}
\hline Level of & \multicolumn{2}{c}{ Father } & \multicolumn{2}{c}{ Mother } \\
\cline { 2 - 5 } Education & Frequency & $\begin{array}{c}\text { Percentage } \\
(\boldsymbol{\%})\end{array}$ & Frequency & $\begin{array}{c}\text { Percentage } \\
(\boldsymbol{\%})\end{array}$ \\
\hline $\begin{array}{c}\text { No School } \\
\text { Elementary } \\
\text { School }\end{array}$ & 0 & 0 & 0 & 0 \\
$\begin{array}{c}\text { Junior High } \\
\text { School }\end{array}$ & 10 & 20 & 2 & 5 \\
$\begin{array}{c}\text { Senior High } \\
\text { School }\end{array}$ & 19 & 25 & 9 & 22 \\
$\begin{array}{c}\text { University } \\
\text { Total }\end{array}$ & 3 & 47 & 26 & 65 \\
\hline Sources: Primary Data of Questionnaire & & 8 \\
\hline
\end{tabular}

Characteristics of Respondents by Occupational of Parents

Table 3. Distribution of Respondents by Occupational of Parents in Taman Kanakkanak Dharma Wanita Godean Nganjuk District $(n=40)$.

\begin{tabular}{ccccc}
\hline \multirow{2}{*}{ Occupational } & \multicolumn{2}{c}{ Father } & \multicolumn{2}{c}{ Mother } \\
\cline { 2 - 5 } & Frequency & $\begin{array}{c}\text { Percentage } \\
(\boldsymbol{\%})\end{array}$ & Frequency & $\begin{array}{c}\text { Percentage } \\
(\boldsymbol{\%})\end{array}$ \\
\hline No Work & 0 & 0 & 17 & 42 \\
Farmer & 15 & 37 & 5 & 13 \\
Entrepreneur & 15 & 37 & 12 & 30 \\
Civil Servants & 7 & 18 & 6 & 15 \\
Army/ Police & 3 & 8 & 0 & 0 \\
\hline Total & 40 & 100 & 40 & 100 \\
\hline
\end{tabular}

Sources: Primary Data of Questionnaire

Based on the research data in table 3 , it was found that a small proportion of 15 parents $(37 \%)$ fathers worked as farmers and entrepreneurs. In addition, almost half of the 17 respondents $(42 \%)$ of mothers did not work.

Characteristics of Respondents by Parents Ever or Never Get Information About Parenting Parents

Based on the research data in table 4 , it was found that most of the 21 parents $(52 \%)$ fathers had ever received information about parenting. In addition, most of the 23 parents (57\%) mothers had ever received information about parenting.
Table 4. Distribution of Respondents by Parents Ever or Never Get Information About Parenting Parents in Taman Kanak-kanak Dharma Wanita Godean Nganjuk District $(\mathrm{n}=$ 40).

\begin{tabular}{ccccc}
\hline $\begin{array}{c}\text { Ever or } \\
\text { Never Get } \\
\text { Information } \\
\text { About }\end{array}$ & Frequency & $\begin{array}{c}\text { Percentage } \\
(\boldsymbol{\%})\end{array}$ & Frequency & $\begin{array}{c}\text { Percentage } \\
(\boldsymbol{\%})\end{array}$ \\
$\begin{array}{rlccc}\text { Parenting } \\
\text { Parents }\end{array}$ & & & & \\
\hline Ever & 21 & 52 & 23 & 57 \\
Never & 19 & 48 & 17 & 43 \\
\hline Total & 40 & 100 & 40 & 100 \\
\hline Sources: Primary Data of Questionnaire
\end{tabular}

\section{Characteristics of Respondents by Age of Child}

Table 5. Distribution of Respondents by Age of Child in Taman Kanak-kanak Dharma Wanita Godean Nganjuk District $(n=40)$.

\begin{tabular}{ccc}
\hline $\begin{array}{c}\text { Age of Child } \\
\text { (Years) }\end{array}$ & Frequency & Percentage (\%) \\
\hline 3 & 3 & 7 \\
4 & 8 & 20 \\
5 & 17 & 43 \\
6 & 12 & 30 \\
\hline Total & 40 & 100 \\
\hline Sources: Primary Data of Questionnaire
\end{tabular}

Based on Table 5 shows that from almost half of 17 parents (43\%) children aged 5 years.

\section{Characteristics of Respondents by Gender of} Child

Table 6. Distribution of Respondents by Gender of Child in Taman Kanak-kanak Dharma Wanita Godean Nganjuk District $(\mathrm{n}=$ 40).

\begin{tabular}{cccc}
\hline No & $\begin{array}{c}\text { Gender of } \\
\text { Child }\end{array}$ & Frequency & $\begin{array}{c}\text { Percentage } \\
(\boldsymbol{\%})\end{array}$ \\
\hline 1 & Male & 16 & 40 \\
2 & Female & 24 & 60 \\
\hline & Total & 40 & 100 \\
\hline
\end{tabular}

Sources: Primary Data of Questionnaire

Based on Table 6 shows that of the 40 parents most of the 24 parents $(60 \%)$ were female.

Characteristics of Respondents by Number of Siblings 
Based on Table 7 shows that the majority of 21 parents (53\%) children have 2 siblings.

Table 7. Distribution of Respondents by Number of Siblings in Taman Kanak-kanak Dharma Wanita Godean Nganjuk District ( $\mathrm{n}=$ 40).

\begin{tabular}{cccc}
\hline No & $\begin{array}{c}\text { Number of } \\
\text { Siblings }\end{array}$ & Frequency & $\begin{array}{c}\text { Percentage } \\
(\boldsymbol{\%})\end{array}$ \\
\hline 1 & 1 person & 3 & 7 \\
2 & 2 person & 21 & 53 \\
3 & $\geq 3$ person & 16 & 40 \\
\hline & Total & 40 & 100 \\
\hline
\end{tabular}

Sources: Primary Data of Questionnaire

Characteristics of Respondents by Who Lives at Home

Table 8. Distribution of Respondents by Who Lives at Home in Taman Kanak-kanak Dharma Wanita Godean Nganjuk District $(n=40)$.

\begin{tabular}{clcc}
\hline No & \multicolumn{1}{c}{$\begin{array}{c}\text { Who Lives at } \\
\text { Home }\end{array}$} & Frequency & $\begin{array}{c}\text { Percentage } \\
(\boldsymbol{\%})\end{array}$ \\
\hline 1 & $\begin{array}{l}\text { Father, Mother, } \\
\text { and Siblings }\end{array}$ & 28 & 70 \\
2 & $\begin{array}{l}\text { Father, Mother, } \\
\text { Siblings, } \\
\text { Grandmother, and } \\
\text { Grandfather }\end{array}$ & 12 & 30 \\
\hline & & \\
\hline Total & 40 & 100 \\
\hline Sources: Primary Data of Questionnaire
\end{tabular}

Based on Table 8 shows that of the 40 parents most of the 28 parents $(70 \%)$ their children live in the same house as their fathers, mothers and siblings.

Characteristics of Respondents by Parental Relations with Children

Table 9. Distribution of Respondents by Parental Relations with Children in Taman Kanak-kanak Dharma Wanita Godean Nganjuk District $(n=40)$.

\begin{tabular}{cccc}
\hline No & $\begin{array}{c}\text { Parental } \\
\text { Relations with } \\
\text { Children }\end{array}$ & Frequency & $\begin{array}{c}\text { Percentage } \\
(\boldsymbol{\%})\end{array}$ \\
\hline 1 & Father & 9 & 22 \\
2 & Mother & 31 & 78 \\
\hline & Total & 40 & 100 \\
\hline Sources: & Primary
\end{tabular}

Based on Table 9 shows that from 40 parents almost 31 parents (78\%) who were willing to become respondents were mothers.
Examination of the Correlation Between Parenting Patterns and Mental-Emotional Development at Taman Kanak-Kanak Dharma Wanita Godean, Nganjuk District

Table 10. The Correlation Between Parenting Patterns and Mental-Emotional Development at Taman Kanak-Kanak Dharma Wanita Godean, Nganjuk District $(n=40)$.

\begin{tabular}{|c|c|c|c|c|c|c|c|c|}
\hline \multirow{3}{*}{$\begin{array}{l}\text { Parenting } \\
\text { Patterns }\end{array}$} & \multicolumn{6}{|c|}{ Mental-Emotional Development } & \multicolumn{2}{|c|}{ Total } \\
\hline & \multicolumn{2}{|c|}{$\begin{array}{c}\text { Not } \\
\text { experienced }\end{array}$} & \multicolumn{2}{|c|}{$\begin{array}{c}\text { Possible } \\
\text { Experiences }\end{array}$} & \multicolumn{2}{|c|}{ Interference } & & \\
\hline & $f$ & $\%$ & $f$ & $\%$ & $f$ & $\%$ & $\sum$ & $\%$ \\
\hline Otoriter & 2 & 5 & 6 & 15 & 1 & 2,5 & 9 & 22,5 \\
\hline Neglectful & 1 & 2,5 & 0 & 0 & 1 & 2,5 & 2 & 5 \\
\hline Indulgent & 2 & 5 & 3 & 7,5 & 1 & 2,5 & 6 & 15 \\
\hline Authoritative & 18 & 45 & 5 & 12,5 & 0 & 0 & 23 & 57,5 \\
\hline Combination & 0 & 0 & 0 & 0 & 0 & 0 & 0 & 0 \\
\hline Total & 23 & 57,5 & 14 & 35 & 3 & 7,5 & 40 & 100 \\
\hline
\end{tabular}

Sources: Primary Data of Questionnaire

Based on Table 10 shows that from 40 parents almost half of 18 parents $(45 \%)$ had authoritative parenting and their children did not experience emotional mental development disorders. Based on the results of statistical tests with SPSS version 23 for Windows obtained Coefficient Contigency $\rho$ value $=$ $0.011 \leq \alpha=0.05$. So, Ha is accepted and Ho is rejected, meaning there is a correlation between parenting patterns and mental-emotional development at Taman Kanak-Kanak Dharma Wanita Godean, Nganjuk District.

\section{DISCUSSION}

\section{Parenting Patterns}

Based on table 10, it was found that out of 40 parents, most of the 23 parents $(57.5 \%)$ had authoritative parenting types. In the education of mothers who have the type of authoritative parenting from 23 parents, almost all 22 parents $(95.65 \%)$ of mothers with high school education and father education were almost half of 21 parents $(30.4 \%)$ fathers with elementary, juniors high school, and seniors high school education. In relation to parents who have authoritative parenting from 23 parents, most of the 16 parents $(69.56 \%)$ are mothers. Based on the results of the Coefficient Contigency statistical test with SPSS 23 Version For Windows program found that the education of mothers with parenting parents with a significance level $\rho$ value $=0.001 \leq \alpha=0.05$ 
and father education with parenting parents with a significance level $\rho$ value $=0.029 \leq \alpha=$ 0.05 . So that parenting is influenced by mother's education and father's education.

According to Baumurind (2004), authoritative parenting encourages children to be independent by setting control limits. Parents are usually warm and compassionate towards their children, making a positive impact that is children feel happy, have selfcontrol, confidence is nurtured, can cope with stress, have the desire to achieve, and can communicate well with friends and adults. According to Astutik (2008), the application of parenting is positive attitudes from parents so that they can be used as examples or role models for their children.

Several factors influence the role of care, including parents' age, parental involvement, prior experience, and parental education (Astutik, 2008). Specific age ranges have strong reasons in relation to perform the role of parenting, when too young or too old lets unable to perform optimally care. The closeness of father and child relationships is as important as the relationship between mother and child although naturally there will be differences, but in some fathers it can involve interacting as an effort in childcare. Parents who have had previous experience in caring for children will be better prepared to carry out the care role and be more relaxed. Parent's education in caring for children will affect their readiness in carrying out parenting roles.

Based on the facts and theories above, researchers argue that parenting parents are at Taman Kanak-kanak Dharma Wanita Godean, Nganjuk District influenced by the mother's education and father's education. Where parents who have a high level of education and knowledge will be more active in seeking information to improve their knowledge and skills in parenting, so usually parents who have higher education will tend to apply good parenting to their children by applying authoritative parenting.

\section{Mental-Emotional Development}

Based on table 10, it was found that from 40 parents, most of the 23 parents $(57.5 \%)$ had no emotional mental development disorders. In the work of mothers of 23 parents whose children did not experience mental emotional disorders most of the 14 parents $(60.9 \%)$ of mothers did not work. In children living at home from 23 parents whose children did not experience emotional mental development disorders most of the 20 parents $(86.95 \%)$ children lived at home with their fathers, mothers and siblings and a small portion of 3 parents (13.04\%) children live with their father, mother, siblings, grandmother and grandfather. Based on the results of the Coefficient Contingency statistical test with SPSS V23 For Windows program found that the work of mothers with mental emotional development with a significance level $\rho$ value $=0.043 \leq \alpha=$ 0.05 and children living at home related to mental emotional development with significance level $\rho$ value $=0.021 \leq \alpha=0.05$. So that emotional mental development is influenced by the work of mothers and children living at home (relationships with family members).

According to Yusuf (2011), the problem of emotional mental development is influenced by several factors including parenting, genetic, relationships with family members. Implementation of effective parenting can help children to control mental emotional. Preschoolers experience growth and development at the basic stage which lasts short or is called the golden period, this is very influential and becomes the basis for further development so that mental emotional development must be controlled so that emotional mental disorders will not occur later.

According to Prameswari (2013), the relationship with family members is also known as a risk factor for mental emotional problems in children, because the kinship between children and parents and grandchildren with grandmother and grandfather is very close, the existence of grandparents is inseparable from growth and development child. Entrusting childcare to grandmother and grandfather on the one hand is indeed beneficial to be one source of help, support and encouragement. They are more experienced, know better what to do if grandchildren are not feeling well, do not want to eat, cry and so on. The problem of love is also no doubt. They will wholeheartedly provide the best for their grandchildren. But sometimes the intervention of grandmother and grandfather in caring for children is often not in line with parents. Grandma and grandfather make their own rules, even though their children are adults and have a family in the eyes 
of their grandmother and grandfather, the child is still considered a child and is considered inexperienced in caring for and caring for children. Rules that their children make are too complicated and difficult. Grandma and grandfather feel that raising grandchildren is an opportunity to make up for the mistakes they once made while caring for their children. The parenting that is applied usually tends to be permissive (giving more grandchildren the freedom to do whatever they want and get what they want). Parenting is not in line between grandparents' parents and grandmothers, can make the psychological development of children become unbalanced children.

Based on the facts and theories above, researchers argue that emotional mental development at Taman Kanak-kanak Dharma Wanita Godean, Nganjuk District influenced by maternal work factors and relationships with family members. Children who live with their father, mother, siblings, grandmother and grandfather in the family get a role to care for grandchildren, a grandmother applies a permissive parenting pattern, is too indulgent, and obeys all of her grandchildren's requests. This is not good for children, because if the child is too cared for permissively, the child will become a child who has temperament characteristics.

The Correlation Between Parenting Patterns and Mental-Emotional Development at Taman Kanak-Kanak Dharma Wanita Godean, Nganjuk District

Based on table 10, it was found that out of 40 parents, most of the 23 parents $(57.5 \%)$ had authoritative parenting. While almost half of 23 parents $(45 \%)$ of children did not experience emotional mental development. Nearly half of the 18 parents (45\%) had authoritative parenting and the child did not experience emotional mental development disorders, a small percentage of 5 parents $(12.5 \%)$ were likely to experience emotional mental development and none of the 0 (zero) parents $0 \%$ ) children experience emotional mental development disorders. Test results of Coefficient Contigency statistics with SPSS V23 For Windows program get $\rho$ value $=0.011$ $\leq \alpha=0.05$. So that $\mathrm{Ha}$ is accepted means there is a relationship of parenting parents with preschool mental emotional development in
Taman Kanak-Kanak Dharma Wanita Godean, Nganjuk District.

According to Wijanarko and Setiawati (2016), parents with the type of authoritative parenting provide freedom to children to choose and carry out an action, and their approach to children is warm. Family decisions involve children's opinions and are only decided as a joint decision. Children will grow independently, are accustomed to expressing opinions, are often talking, can control themselves, have good relationships with friends, are able to deal with stress, have new interests, and are cooperative with others.

According to Priyatna (2010), parenting parents' permissiveness can make a child feel free to do whatever he wants. Parenting is too hard so that children become familiar with a threatening atmosphere. Neglectful parenting lacks warmth, low level of parental care for their children, and lack of supervision from parents. In addition, the influence of the behavior of siblings at home.

Based on the facts and theories above, researchers argue that there is a relationship between parenting parents with preschool mental emotional development at Taman Kanak-kanak Dharma Wanita Godean, Nganjuk District. The type of authoritative parenting parents encourages the full desires of the child but with certain limitations set by parents. Parents make children more open and tell a lot about the events they experienced outside the home. In this study, children are more likely not to experience emotional mental development due to authoritative parenting parents make children accustomed to democratic patterns. In addition, parents teach children to have a good stress mechanism so that they can overcome emotional mental development.

\section{CONCLUSION}

Based on the results of the study there are several things that can be concluded, among others:

1. Most of the 23 parents (57.5\%) of preschool children in Taman KanakKanak Dharma Wanita Godean, Nganjuk District received authoritative parenting.

2. Most of the 23 parents $(57.5 \%)$ preschool children at Taman Kanakkanak Dharma Wanita Godean, 
Nganjuk District not experiencing emotional mental development disorders.

3. There is a relationship to parenting parents with preschool mental emotional development in Taman Kanak-kanak Dharma Wanita Godean, Nganjuk District dengan $\rho$ value $=$ $0,011 \leq \alpha=0,05$.

\section{SUGGESTION}

1. For parents can provide appropriate parenting in the mental emotional development of preschoolers, so that children can develop according to age.

2. For Health Institutions can be a source of information and input to optimize health programs and policy making to address the mental emotional development of preschoolers.

3. For educational institutions can be an additional reference in the development of research on the relationship of parenting parents with the mental emotional development of preschoolers.

4. For the community can be used as additional information to the community which is used as an effort to improve parenting parents in preschool children.

\section{REFERENCES}

-------. (2007). Perkembagan Anak, Edisi 11, Jilid 1. Jakarta: Penerbit Erlangga.

--------. (2009). Buku Ajar Keperawatan Pediatrik Wong. Alih Bahasa: Agus Sutarna, Neti. juniarti, H.Y. Kuncoro. Editor Edisi Bahasa Indonesia : Egin Komara Yudha...[et al]. Jilid 1(Ed. 6). Jakarta: EGC.

Arikunto, S. (2014). Prosedur Penelitian. Jakarta: Rineka Cipta.

Astutik, Ponny Retno. (2008). Meredam Bullying: 3 Cara Efektif Menanggulangi Kekerasan Pada Anak. Jakarta: Grasindo.

Baharuddin. (2009). Pendidikan dan Psikologi Perkembangan . Yogyakarta: ArRozzMedia.

Baumrind. (2004). Pola Asuh Otoritas Orang Tua. Jakarta: Yayasan OborIndonesia.

BPS Jatim. (2016). Badan Pusat Statistik Jawa Timur. Accessed on February 12, 2018 at
00.50 WIB from http://www.bpsjatim.com/.

Davies, Teifion. (2009). ABC Kesehatan Mental. Jakarta: EGC.

Desmita. (2012). Psikologi Perkembangan Peserta Dididk . Bandung: PT Remaja Rosdakarya.

Dinasti, P. (2017). Pola Asuh Orang Tua dengan Perilaku Bullying Anak Usia 1012 Tahun di SDN Pehserut 1 Kecamatan Sukomoro. Skripsi: STIKes Satria Bhakti Nganjuk.

Gottman, J. (2008). Mengemangkan Kecerdasan Emosional Anak. Jakarta: PT Gramedia Pustaka Utama.

Gunarsa, D. (2008). Psikologi Perkembangan Anak dan Remaja . Jakarta: PT BPK Gunung Mulia.

Hidayat, A, A. (2007). Riset Keperawatan dan Teknik Penulisan Ilmiah Ed. 2. Jakarta: Salemba Medika.

Hurlock, E. (1991). Perkembangan Anak, Edisi 6, Jilid 1. Jakarta: Penerbit Erlangga.

IDAI. (2002). Deteksi Dini Tanda Dan Gejala Penyimpangan Pertumbuhan Dan Perkembangan Anak. Surabaya: IDAI Jatim.

Izzaty, R.E. (2006). Prediktor Permasalahan Perilaku Anak Usia Dini Taman Kanakkanak. Tesis, tidak diterbitkan. Yogyakarta: Program Pasca Sarjana Universitas Gadjah Mada.

Luthfia, N., \& Elsa, N. (2014). Hubungan Pola Asuh Otoritatif Dengan Perkembangan Mental Emosional Pada Anak Usia Pra Sekolah Di TK Melati Putih Banyu Manik. Bali: Jurusan Keperawatan Fakultas Kedokteran Universitas Diponegoro.

Mashar, D. (2011). Emosi Anak Usia Dini dan Strategi Pengemangannya, Edisi 1. Jakarta: Kencana.

Moersintowati. (2008). Tumbuh Kembang Anak dan Remaja. Jakarta: IDAI.

Nursalam. (2016). Metodologi Penelitian Ilmu Keperawatan Ed. 4. Jakarta: Salemba Medika.

Plutchik, R. (2003). Emotion and Life, Perspectives from Psychology, Biology, and Evolution. Washington, DC: American Psychological Association.

Prameswari. (2013). Bagaimana Bila Anak diasuh Kakek dan Neneknya. Accessed on April 26, 2018 at 20.45 WIB from http://www.republika.co.id/berita/gayahid 
up/ parenting/12/06/27/m69lj2-

bagaimanakahbila-anak-diasuh-kakek-

dan-neneknya/.

Prastito. (2010). Perkembangan Sosio Emosional Anak. Jakarta: Universitas Terbuka.

Priyatna, Andri. (2010). Let's End Bullying Memahami, Mencegah, dan Mengatasi Bullying. Jakarta: PT Elex Media Komputindo.

Santrock, W, J. (2011). Perkembangan Anak Edisi 7, Jilid 2 (Terjemahan Sarah Genis $B)$. Jakarta: Erlangga.

Sari, Dwi Puspita. (2012). Hubungan Pola Asuh Orang Tua dengan Terjadinya Phobia Sekolah Pada Anak Prasekolah (Di PAUD Al-Alim Kecamatan Wonosari Kabupaten Madiun). Skripsi: STIKes Satria Bhakti Nganjuk.

Soetjiningsih, IG, N., Y, J., \& et, al. (2015). Tumbuh Kembang Anak, Edisi 2. Jakarta: Buku Kedokteran EGC.

Wijanarko, Jarot dan Esther Setiawati. (2016). Ayah Baik-Ibu Baik Parenting Era Digital Pengaruh Gadget dan Perilaku terhadap Kemampuan Anak. Jakarta: Keluarga Indonesia Bahagia.

Wong, dkk. (2008). Buku Ajar Keperawatan Pediatrik Wong. Alih Bahasa: Agus Sutarna, Neti. juniarti, H.Y. Kuncoro. Editor Edisi Bahasa Indonesia : Egin Komara Yudha...[et al]. Volume 2 (Ed. 6). Jakarta: EGC.

Yusuf, S. (2011). Psikologi Perkembangan Anak dan Remaja. Bandung: PT.Remaja Rosdakarya.

Zaviera, Ferdinand. (2008). Memahami Tumbuh Kembang Anak. Jogjakarta: Katahati.

Cite This Article As: Utami, R. B. \& Rosada, A. Parenting Patterns of Parents and MentalEmotional Development in Taman KanakKanak Dharma Wanita Godean, Nganjuk District. Nurse and Health: Jurnal Keperawatan 2018; 7(2): 113-120. 